\title{
THE USE OF SILICIUM SOLID-STATE DETECTOR \\ IN SOLAR X-RAY MEASUREMENTS
}

B. VALNIČEK

Observatory Ondřejov, Ondřejov, C.S.S.R.

\begin{abstract}
The silicium solid-state detector has been used as control-detector in the $\mathrm{X}$-ray photometer system on board of the satellite Interkosmos 1 .

The effectiveness of the use of such detector as control-unit for radiation-belts has been confirmed also as independent indicator of high energy X-ray quants during high levels emission of solar active regions.
\end{abstract}

